DOI: $10.1515 /$ pof-2017-0014

VOLUME 9, ISSUE 2, 2017

ISSN: $2036-5438$

\title{
The Interpretive Function of the CJEU and the Interrelationship of EU and National Levels of Consumer Protection
}

by

Geraint Howells and Gert Straetmans * 


\section{Abstract}

This paper analyses the ways in which the Unfair Contract Terms and Unfair Commercial Practices Directives try to steer a path between imposing a common European standard and allowing national variation. The open wording of the norms and safeguard clauses in both directives allows room for their flexible application. The differentiated role between the Court of Justice, as the interpreter of European law, and the national courts, as the party that applies it, provides a release valve to prevent any direct clashes and allows a subtle way for national perspectives to be reflected.

The analysis finds that, irrespective of the underlying level of harmonisation, and with the backing of the European legislator's intention of ensuring a high level of consumer protection, the CJEU is gradually painting the average European consumer with more realistic features. Here, the case law of the CJEU fulfils a bridging function between the labelling requirements in the Foodstuff Regulation, the transparency requirements in the Unfair Contract Terms Directive and the informed decision requirements in the Unfair Commercial Practices Directive. In these three domains the CJEU recognises that the level of customer attention may be suboptimal, even in the presence of comprehensive and correct information.

The CJEU's approach contributes to more convergence in consumer protection throughout the EU. Yet, in terms of legitimacy, it must be noted that in all cases the CJEU has maintained a clear distinction between interpretation and application. The particular constitutional legal order in which the CJEU operates only allows for a process whereby the contours of a more coherent European consumer protection policy are gradually revealed. In the absence of sufficient legislative guidance at the European and national levels, national courts may be increasingly informed by the case law of the CJEU in an effort to establish clearly desirable common expectations. Those who believe that, in practice, uniformity can be achieved overnight by simply adopting a common maximum norm appear over-optimistic. 
Key-words

Unfair Contract Terms Directive, Unfair Commercial Practices Directive, interpretive function of the CJEU, levels of consumer protection, average consumer 


\section{Introduction}

The EU's extensive engagement with consumer protection law is well documented (Howells 2017). It sees a European approach to these issues as a means of removing barriers to trade, and to the creation of a common competitive environment. However, the extent to which full harmonisation is possible or desirable is debated. We take two directives - one in which a minimum harmonization approach has been adopted (Directive 93/13/EEC on Unfair Contract Terms) and the other in which a maximum harmonization approach has been adopted (Directive 2005/29/EC on Unfair Commercial Practices). We first note the ways in which this legislation tries to steer a path between imposing a common European standard and allowing national variation. The Unfair Contract Terms Directive (UCTD) seeks to limit national discretion by structuring the standard, and use of, an indicative list, whereas, despite adopting a maximum harmonisation approach, the Unfair Commercial Practices Directive (UCPD) has limits to its scope, and exceptions allowing for some national traditions. Moreover, the open textured nature of the norms allows room for flexible application.

This leads on to our second point of discussion relating to the role of the courts in developing common norms. Central to this discussion is the differentiated role between the Court of Justice of the European Union (CJEU) as the interpreter of European law and the national courts as the party that applies it. This relationship provides a release valve to prevent any direct clashes, and allows a subtle way for national perspectives to be reflected.

According to Article 4(2) a TFEU the establishment of the internal market is built on a competence which is shared between the Union and the Member States. According to Lenaerts the CJEU has continually been called upon to uphold the 'rule of law' as provided for by Article 19 TEU (Lenaerts 2015, 14-15). In his view, the Court at first exercised a gap-filling function ${ }^{\mathrm{I}}$ and later aimed to safeguard the core of the European integration set out in the Treaty. Once the constitutional foundations of the EU legal order were put in place and the establishment and functioning of the internal market secured, the CJEU moved into a new paradigm. As the constitutional court of a more mature legal order, it now sees its role primarily as one of upholding the 'checks and balances' built into the EU's constitutional legal order of states and peoples, including the protection of human 
rights, displaying greater deference to the preferences of the EU legislator or to those of the Member States (Lenaerts 2015, 16).

In contrast with other subdomains of EU law, internal market policy has not recently been the subject of (identity) crises. The establishment of the internal market as such is not put into question in consumer law literature either, rather at some occasions the manner in which it has been given concrete shape has been queried. Hence, the constitutional/administrative paradigm debate does not play a predominant role in the domain of consumer protection policy. Viewed from a consumer protection angle, the EU legal order presents itself as a genuine construct that can objectively be reduced to one or other traditionally defined paradigm. As a result, it may be submitted. alongside Lenaerts, that the CJEU is a constitutional court of a more mature legal order that upholds checks and balances, and which, depending on circumstances, displays greater deference to preferences of the EU legislator or to those of the Member States.

That being said, the Court of Justice case law relating to consumer protection can leave more or less discretion to national courts, and in respect of unfair commercial practices the Court has fiercely cracked down on national laws that seem to infringe the scope of the Directive. However, we see this as a dialogue that allows for gradual convergence, and use national case law to see how effective this is. An exhaustive account of the cases related to the UCTD and UCPD goes far beyond the purpose of this paper. Instead of reporting an extensive number of cases, we selected cases that are most illustrative of the research question of this contribution, and of the directives under investigation.

An important insight from our research is that the concept of the average consumer that has been so heavily criticized by consumer movements for having unrealistic expectations of actual consumer behaviour, is in the practice of the CJEU actually more realistic, and even protective of consumers.

We firstly analyse the UCTD (Section 2) and subsequently the UCPD (Section 3). To enhance the reader friendliness of the paper the same format is applied. Firstly, we clarify the general scheme of the directives (subsections A), followed by an overview of relevant case law of the CJEU (subsections B). These analyses are complemented with an actual and illustrative account of relevant national cases (subsections C). Finally, a conclusion is drawn in Section 4. 


\section{Unfair Contract Terms Directive}

\subsection{The Directive's unfairness standard}

Art. 3(1) provides: 'A contractual term which has not been individually negotiated shall be regarded as unfair if, contrary to the requirement of good faith, it causes a significant imbalance in the parties' rights and obligations arising under the contract, to the detriment of the consumer'.

Art. 4(2) provides: 'Assessment of the unfair nature of the terms shall relate neither to the definition of the main subject matter of the contract nor to the adequacy of the price and remuneration, on the one hand, as against the services or goods supplies in exchange, on the other, in so far as these terms are in plain intelligible language'.

There is an annex of indicatively unfair terms. Inclusion in the annex does not create any formal presumption of unfairness, though in practice courts do take notice of whether challenged terms are similar to those found in the Annex. The Annex includes exclusion and limitation clauses and also penalty clauses. The other terms in the Annex deal more with ensuring there is a balance between the two parties - this fits in with the core requirement that there be a significant imbalance. These have been classified as terms that (i) give one party control over the contract terms or the performance of the contract, (ii) control the duration of the contract and (iii) which prevent the parties having equal rights (Howells 1997, 106-107).

\subsubsection{Good faith and significant imbalance}

Good faith is not an independent test of unfairness, but rather is linked to the establishment of a significant imbalance. Recital 15 provides that

'Whereas the assessment, according to the general criteria chosen, of the unfair character of terms, in particular in sale or supply activities of a public nature providing collective services which take account of solidarity among users, must be supplemented by a means of making an overall evaluation of the different interests involved; whereas this constitutes the requirement of good faith; whereas, in making an assessment of good faith, particular regard shall be had to the strength of the bargaining positions of the parties, whether the consumer had an inducement to agree to the term and whether the goods or services were sold or supplied to the special order of the consumer; whereas the 
requirement of good faith may be satisfied by the seller or supplier where he deals fairly and equitably with the other party whose legitimate interests he has to take into account'.

Does this standard only require a clear conscience and use or transparent procedures, or as the recital suggests is a contractor required to take some account of the legitimate interests of the other party? (Farnsworth 1962, 666; Brownsword 1994, 197)

The CJEU has interpreted this as requiring an assessment of "whether the seller or supplier could reasonably assume that the consumer would have agreed to the term concerned in individual contract negotiations'. II Moreover, does good faith go beyond mere procedural controls, and require that some terms be always considered unfair as they are so seriously imbalanced? As Hugh Beale comments

I suspect that good faith has a double operation. First, it has a procedural aspect. It will require the supplier to consider the consumer's interests. However, a clause which might be unfair if it came as a surprise may be upheld if the business took steps to bring it to the consumer's attention and to explain it. Secondly, it has a substantive content: some clauses may cause such an imbalance that they should always be treated as [...] unfair (Beale 1995, 245).

Whatever, the meaning of good faith, the requirement of significant imbalance indicates that there must be some substantive unfairness. There are judicial statements in which assessment of imbalance should involve a comparison with the legal position without the term. ${ }^{\text {III }}$ Exclusion and limitation clauses are therefore obvious such targets of this regulation. One approach to evaluating imbalance is to ask whether the consumer would reasonably accept the term if it was drawn to their attention. ${ }^{\text {IV }}$ The CJEU sees this as part of the good faith test, ${ }^{\mathrm{V}}$ whereas it might be better to ask that question to establish whether there is a substantive imbalance. If an imbalance were found then there might be a consideration of whether it was contrary to good faith, and factors such as transparency and any justifications for using the term could be taken into account. The possible agreement test looks at fairness from the consumer's perspective, but the good faith standard also raises the distinct question of the extent to which the supplier has to take consumer's interests into account.

The ambiguous nature of the good faith test is perplexing when trying to distil the ultimate rationale for the regulation of unfair terms. However, it can be very useful as a 
cloak for the differential application of the norms between legal systems. In this respect, it can be recalled that the minimum harmonisation level of the UCTD allows Member States to adopt a stricter unfairness test; for instance, Belgian legislation, in transposition of the directive, does not refer to good faith as part of the unfairness test.

\subsubsection{Core terms}

The exclusion in art. 4(2) of what might loosely be called core terms underlines that the Directive is not concerned with the fairness of the core bargain. Recital 19 explains: 'assessment of unfair character shall not be made of terms which describe the main subject matter of the contract nor the quality/price ratio of the goods or services supplied'. Market forces should discipline such terms: allowing their challenge would interfere with freedom of contract (Brandner 1991, 647). Consumers can be expected to look after these matters for themselves. Regulation is needed of those more technical terms that consumers will not think to consider, or even be able to evaluate, and yet can cause them unfair surprises. The ability to have a broad or narrow interpretation of art. 4(2) is another lever to have a more or less uniform approach.

\subsubsection{Plain and intelligible language}

Terms must be drafted in plain and intelligible language. ${ }^{\text {VI }}$ The sanction is to interpret the term in the manner most favorable to the consumer. ${ }^{\text {VII }}$ If core terms are not drafted accordingly, they will be subject to assessment for fairness. The average consumer was invoked to ensure that legal and technical jargon should be eschewed (Willett 2007, 328332). Terms must not only be formally understood, but their consequences should also be understandable by the average consumer. This is part of a broader transparency requirement. The extent to which this is embraced can again affect the level of uniformity.

\subsection{CJEU case law}

\subsubsection{Procedural effectiveness}

The case law of the CJEU has been far richer and more expansive than might have been anticipated (Wilhemsson 2017; Micklitz 2014, 771). Much of this has been of a procedural nature, controlling the use of arbitration clauses, ${ }^{\text {VIII }}$ ensuring procedural time limits do not prevent redress, ${ }^{\mathrm{IX}}$ requiring interlocutory remedies be available ${ }^{\mathrm{X}}$ and requiring 
that courts adopt an ex officio doctrine to consider unfair terms of their own motion. ${ }^{\mathrm{XI}}$ This jurisprudence will not be dealt with here.

\subsubsection{General approach}

The preliminary reference is a co-operative procedure between the CJEU and national courts (art. 267 TFEU). The CJEU's role is to interpret EU law, but it is for national courts to apply it. The CJEU has described the unfairness test as vague, ${ }^{\mathrm{XII}}$ and has wanted to give guidance on the test and the annex. Yet, it has appreciated that it would be overburdened given the potentially large number of unfair terms that might be referred. Although in Océano Grupo Editorial $S A v$ Murciano Quintero, ${ }^{\mathrm{XIII}}$ the CJEU was willing to hold that a jurisdiction clause in a contract for the sale of encyclopaedias must be unfair, the Court backtracked in Freiburger Kommunalbauten GmbH Bangesellschaft \& Co KG v Hofstetter ${ }^{\mathrm{XIV}}$ and even accepted that the fairness assessment needed to take account of national law and the factual matrix. ${ }^{\mathrm{xv}}$

\subsubsection{Significant imbalance and good faith}

The CJEU has only recently started to give guidance on the core elements of the fairness test. In Aziz, it noted that in referring to concepts of good faith and significant imbalance in the parties' rights and obligations arising under the contract, to the detriment of the consumer, Article 3(1) of the directive merely defines in a general way the factors that render unfair a contractual term that has not been individually negotiated' ${ }^{\text {XVI }}$

This seems to support the view that the fairness test is an amalgam of procedural and substantive justice.

The CJEU has said that "to ascertain whether a term causes a "significant imbalance" in the parties' rights and obligations arising under the contract, to the detriment of the consumer, it must in particular be considered what rules of national law would apply in the absence of an agreement by the parties in that regard. Such a comparative analysis will enable the national court to evaluate whether and, as the case may be, to what extent, the contract places the consumer in a legal situation less favourable than that provided for by the national law in force. To that end, an assessment should also be carried out of the legal situation of that consumer having regard to the means at his disposal, under national legislation, to prevent continued use of unfair terms' ${ }^{\text {XVII }}$ 
In Arig, the CJEU stated that 'in order to assess whether the imbalance arises "contrary to the requirement of good faith", it must be determined whether the seller or supplier, dealing fairly and equitably with the consumer, could reasonably assume that the consumer would have agreed to the term concerned in individual contract negotiations'. XVIII

As suggested above, this may be a better test of whether there is significant imbalance rather than a lack of good faith. The fact that the Court uses this test in the context of good faith indicates that use of a substantively unfair term can in itself be contrary to good faith.

\subsubsection{Core terms}

In Kásler v OTP Jelzáogbank ${ }^{\mathrm{XIX}}$ the CJEU noted that under Art. 4(2) the exclusion from assessment of terms relating to the main subject matter of the contract, or the price or remuneration, was an exception that had to be construed strictly. It accepted the core/ancillary term distinction. Terms falling within the 'main subject matter of the contract' are 'those that lay down the essential obligations of the contract and, as such, characterize it'. Ancillary terms are therefore those that do not decide the essence of the contract. Whether the exchange rate for monthly repayments fell within the main subject matter was left to the national courts. ${ }^{\mathrm{x}}$ The Court held that the exclusion for price or remuneration could not apply to a term that simply fixed exchange rates, as that could not be considered remuneration. Previously the exemption had not been applied to a mechanism for amending prices of services in Nemzeti Fogyastovedelmi Hatosag $v$ Invitel Tavkozlesli ZRT. ${ }^{\mathrm{XXI}}$ The CJEU seems to have sent a clear signal that this exemption should be narrowly construed, but its application is again a matter for national law.

\subsubsection{Transparency}

The CJEU has given some very strong guidance on what is required for terms to be plain and intelligible. This is crucial, for even core terms can be reviewed if they fail to meet this standard. In Nemreti Fogyastovedelmi Hatosag v Invitel Tavkozlesli ZRT ${ }^{\mathrm{XXI}}$ it was held that the power to vary the contract had to provide the method for fixing fees and the reasons for amendment. ${ }^{\text {XXII }}$ These had to be set out in plain and intelligible language so consumers could foresee, on the basis of clear intelligible criteria, the amendments that the supplier could make. ${ }^{\mathrm{XxIV}}$ Equally, the importance of consumers knowing how a power to amend 
prices could be exercised was underlined in RWE Vertrieb $v$ Verbraucherzentrale NordrbeinWestfalen EV. ${ }^{\mathrm{XxV}}$ Kásler v OTP Jelzálogbank ZRT ${ }^{\mathrm{XXVI}}$ concerned a complex pricing mechanism for pricing and repayment of a foreign currency loan. The Court made explicit the requirement that intelligibility should not be restricted to mere formal or grammatical intelligibility. The standard to be used is that of the average consumer. The Court used the traditional formula, that such an average consumer should be reasonably well informed, and reasonably observant and circumspect. However, in practice it applied this test in a way which promoted consumer protection. It was not concerned with a mere formal ability to understand. The average consumer should not only be able to understand the difference between buying and selling rates. She must also be able to comprehend the significant economic consequences that may result from the application of the selling rate to the calculation of repayments, and the total sum repaid. ${ }^{\text {XXVII }}$

The standard to be used is that of the average consumer, but the contractual framework may also have an impact on the consumer's level of attention. Van Hove $v$ CNP Assurances $S A^{\mathrm{XXVIII}}$ concerned a loan contract combined with an insurance contract, intended to ensure that mortgage loan repayments were covered. The CJEU emphasized the relevance of the fact that the contract at issue forms part of a broader contractual framework. The Court said that 'the consumer cannot be required, when concluding related contracts, to have the same vigilance regarding the extent of the risks covered by that insurance contract as he would if he had concluded that contract and the loan contracts separately. $x x i x$

In the same vein, the CJEU stressed the importance of the APR in consumer credit contracts in Pohotovost, ${ }^{\mathrm{xxx}}$ and Maria Bucura. ${ }^{\mathrm{xxI}}$ Informing the consumer of the total cost of credit, in the form of an interest rate calculated according to a single mathematical formula, is of critical importance as it contributes to the transparency of the market, enables the consumer to compare offers of credit and enables him to assess the extent of his liability. Hence, 'the failure to mention the APR in the credit agreement at issue, the mention of the APR being essential information in the context of Directive 87/102 (consumer credit), may be a decisive factor in the assessment by a national court of whether a term of a credit agreement concerning the cost of that credit in which no such mention is made is written in plain, intelligible language within the meaning of Article 4 of Directive 93/13, xxxII 


\subsection{National case law}

There are now many lower court decisions in the UK applying the Directive, sometimes in a manner that is very faithful to European law. However, attention has now focussed on Supreme Court decisions that appear to be less consumer friendly. In fact, the Supreme Court has in fact recently considered the transparency test to be opaque, ${ }^{\mathrm{XxXIII}}$ but this approach, when combined with the discretion accorded to national courts in applying the EU law as interpreted by the CJEU, makes it hard to say whether the Supreme Court has wrongly applied the law. Though as a final court it can be criticized for failing to make a preliminary reference where the law seems unclear.

In Director General of Fair Trading v First National Bank plc, ${ }^{\text {XxIV }}$ a term requiring interest to be paid on delayed payments when rescheduling debts was considered fair as it was necessary if interest was to be recoverable. Many of the judgements have demonstrated an appreciation of the European origin of fairness, and an understanding that it is an amalgam of procedural and substantive fairness. Core terms were also distinguished from ancillary or subsidiary terms. It was emphasised that the exemption for core terms should be applied restrictively. The result in this case was seen as disappointing by many consumer activists, but that may be an unfair critique, as there is nothing inherently unfair in reserving the right to default interest under the main contract. This decision can in fact be seen as adopting a European approach to interpretation. However, it can perhaps be criticised for the judges' readiness to accept that the understanding of good faith was settled, and therefore did not merit a reference to the European Court.

The reluctance to refer was also present in Office of Fair Trading $v$ Abbey National plc and Others, ${ }^{\mathrm{xxx}}$ which involved a challenge by the Office of Fair Trading to excessive bank charges incurred through a range of irregular activity by customers. Such charges were central to the financing of the "free-if-in-credit' model that most British current accounts operated under. The question was whether they were subject to review under the Regulations. The Supreme Court viewed the charges as part of the overall package involved for 'free-if-in-credit' accounts and excluded them from review. The deal was free banking in return for banking charges if the account was used unwisely. The charges were an important part of the bank's revenue. The decision not to refer seems difficult to justify. The matter was considered acte clair despite the Court of Appeal and High Court having reached a different conclusion. This runs counter to the House of Lords' decision in First 
National Bank v Office of Fair Trading, where the core terms concept was invoked, and default charges were seen as one, but not the only, term relating to price that remained subject to review. The German Supreme Court has in fact subjected such charges to review. ${ }^{\text {xxxvI }}$ The Supreme Court decision looks even more insecure when assessed against the later CJEU's decision in Arpád Kásler, Hajnalka Káslerné Rábai v OTP Jelálogbank Zrt, ${ }^{\mathrm{Xxx}}{ }$ in which the Court accepted the core/ancillary term distinction. The explanation, but not justification, for failing to make a reference was perhaps the desire to give the banks some respite and security after their many setbacks in recent years. A reference to Europe would have left them uncertain of their liabilities for a significant period of time (Morgan 2010, 208-214).

Parking Eye $v$ Beavis $^{\mathrm{XxXVIII}}$ shows a recent example of the room for legitimate disagreement on how the test should be applied. It concerned the fairness of a $£ 85$ charge for overstaying a two-hour free parking offer. Lord Toulson found that this created a significant imbalance, as it was a greater imposition than the damages normally recovered. ${ }^{\text {XxxIX }}$ He argued that it had not been proven that a consumer would accept the term, and noted that for some consumers this was a hefty sum, that applied even if the overstay was short. In his view, Lords Neuberger and Sumption had erred in holding a term was reasonable, because it was reasonable for the supplier to include the term. They had also been persuaded by the prominence of the term, and the fact that the car park had good reasons to impose the charge to ensure compliance. They also agreed with Lord Mance that it was a fair trade-off for two hours free parking. This case illustrates that the test leaves a lot of discretion, and that even senior judges can come to different conclusions when applying it. These differences seem to be more due to the attitude of the judge to social protection of consumers, than any factor unique to the common law, given the differences between common law judges (Howells, forthcoming).

We mentioned above that there is no or very little legislative guidance on how the transparency requirement must be applied. Consequently, when assessing the transparency of contract terms, national courts enjoy a broad discretion.

Focussing on core terms, the UK Consumer Rights Act 2015 provides that the exemption of Article 4 (2) UCTD applies only if the core term is also prominent. A term is prominent if it is brought to the consumer's attention in such a way that an average consumer would be aware of it (S. 64(4)). In most of the other Member States of the EU 
there is no equivalent requirement to bring core contract terms to the consumer's attention.

The absence of sufficient legislative guidance has led to divergent interpretations of the transparency requirement, despite the gap filling case law of the CJEU referred to above. In Poland for instance, core terms are in conformity with the rule in the directive excluding them from the unfairness test, if they are worded clearly. ${ }^{\mathrm{XL}}$ Yet, the clarity requirement refers to the substance of the standard term concerned, and is satisfied if the term allows for only one possible meaning viewed from the perspective of the average consumer.

French case law remains quite hesitant to apply the transparency principle on core terms (Rochfeld 2004, 981). French courts have historically been quite reluctant to declare a core term null only because of the lack of clarity of that term. Czech case law also shows that the exclusion from the unfairness test of core contract terms is not subject to an elaborate transparency requirement (Illdiko Sik-Simon, 2017).

The most protective approach is to be found in Finland, where core contract terms are not excluded from the unfairness test. A similar protection seems available in Greece, although this does not appear to have been a deliberate legislative choice. Greek legislation omitted an exclusion for core contract terms, so that the protection against unfair terms in consumer contracts extends to cover these. However, influenced by the case law of the CJEU, Greek courts have increasingly interpreted national legislation in conformity with the Directive and the CJEU's case law. In the absence of any legislative guidance on how the transparency principle must be applied, Greek case law developed three principles for the assessment of the transparency of any contract term. First, the principle that contract terms must be clear (grammatically correct and succinct, no obscure terms) and comprehensible (subjective ability of the consumer to realize the term's true meaning); second, the principle of the determinable content of terms (no vague terms); and third, the principle of foreseeability of terms (prohibiting unexpected, unusual, surprising or misleading terms). Businesses must ensure that contract terms correspond to those three principles, assessed from the point of view of an average consumer, who is assumed to be a self-aware and responsible person (Dellios 2015, 118-119).

A broader approach is to be found in Italy, where despite the fact that the Italian legislator also attaches great importance to the transparency of consumer contract terms, and favours the broad reading of transparency provided by the CJEU in Arpad Kasler, , 
Italian courts seem to apply an ex post case-by-case approach by exclusion. Clauses that obviously do not correspond to the transparency requirement are excluded, such as contradictory terms in the consumer contract, as are terms that are drafted in highly technical (financial) language and terms written in an ambiguous, vague language (Giorgianni 2009, 209).

Belgian case law also offers examples of incoherent, and thus non-transparent, terms in consumer contracts. ${ }^{\text {XLII }}$ On one occasion the Liège Court of Appeal was more willing to accept the transparent character of a term in an insurance contract. ${ }^{\text {XLIII }}$ Prior to RWE Vertrieb, cited above, the Brussels Court of Appeal held that the general information duty imposed on businesses does not require the seller to inform the consumer of the consequences of legal requirements, even though these requirements could have had an impact on the fairness of some of the contract terms. ${ }^{\text {XIV }}$

Thus, one can see that case law creates a dialogue between the CJEU and national courts; there is convergence, but also room for national discretion. However, we see in the transparency requirement, and the characterisation of the 'average consumer', that the CJEU has placed the spotlight on the need to ensure consumer protection has practical value for consumers.

\section{Unfair Commercial Practices Directive (UCPD)}

\subsection{Directive's scheme and harmonisation method}

\subsubsection{Broad scope}

The UCPD has a very broad scope. It applies to unfair business-to-consumer (B2C) commercial practices before, during and after a commercial transaction in relation to a product. Furthermore, Article 2(d) of Directive 2005/29 gives a particularly wide definition to the concept of commercial practices: 'any act, omission, course of conduct or representation, commercial communication including advertising and marketing, by a trader, directly connected with the promotion, sale or supply of a product to consumers'. It follows that all types of promotional campaigns, that clearly form part of an operator's commercial strategy and relate directly to the promotion thereof and its sales development, constitute commercial practices. ${ }^{\text {XLV }}$ 
The particularly wide scope of the directive extends to any commercial practice directly connected with the promotion, sale or supply of a product to consumers. Also mixed commercial practices (with $\mathrm{B} 2 \mathrm{C}$ and $\mathrm{B} 2 \mathrm{~B}$ aspects) fall within its scope. According to recital 6 in the preamble to Directive 2005/29/EC, only national legislation relating to unfair commercial practices 'which harm "only" competitors' economic interests or which relate to a transaction between traders is thus excluded from that scope'. ${ }^{\mathrm{XLVI}}$

The general scheme of the directive is characterised by three types of prohibition. First, the general norm of Article 5 functions as a catch all clause, and prohibits unfair commercial practices in general. It provides that a commercial practice is unfair if it is contrary to the requirements of professional diligence and materially distorts, or is likely materially to distort, the economic behaviour of the average consumer with regard to the product.

Second, the directive defines two precise categories of unfair commercial practices, namely misleading practices and aggressive practices. These so-called smaller general norms prohibit misleading and aggressive practices, that having regard to their nature and the factual context cause, or are likely to cause, the average consumer to take a transactional decision which he would not otherwise have taken.

Lastly, Annex I to Directive 2005/29/EC establishes an exhaustive list of 31 (misleading and aggressive) commercial practices which are regarded as unfair in all circumstances. Consequently, these commercial practices alone can be deemed to be unfair without a case-by- case assessment against the provisions of the directive, and in the light of the average consumer.

To apply the UCPD in practice, first it must be verified if the alleged unfair practice is listed in the Annex I black list of the directive. Only if that is not the case can recourse be made to the smaller general prohibitions of misleading and aggressive practices corresponding to the criteria set out in Articles 6 and 7 and in Articles 8 and 9 of Directive 2005/29/EC respectively. If no misleading or aggressive practice can be proven the general norm of Article 5 eventually comes into play.

Directive 2005/29/EC fully harmonises, at the Community level, the rules relating to unfair business-to-consumer commercial practices. Accordingly, Article 4 thereof expressly provides that Member States may not adopt stricter rules than those provided for in the directive, even in order to achieve a higher level of consumer protection. ${ }^{\text {XLVII }}$ Hence, 
Member States no longer enjoy broad discretion to regulate unfair commercial practices. However, the UCPD excludes some practices of its scope and also contains a number of safeguard clauses which allow Member States to further regulate the field. ${ }^{\text {XLVIII }}$

\subsubsection{Excluded practice, safeguard clauses and open norms}

The UCPD does not regulate health and safety rules, rules on taste and decency, contract law, authorisation regimes and deontological rules for liberal professions that are in conformity with EU-law. Member States remain fully competent in those fields subject to other limits imposed by EU-law. The UCPD also contains a number of safeguard clauses. The most important is Article 3(9) on national rules concerning financial services and immovable property. This provision allows Member States to impose requirements which are more restrictive or prescriptive than the Directive.

In Citroën Belux, ${ }^{\text {XLIX }}$ the CJEU interpreted this safeguard clause in favour of the Member States, thereby applying a literal interpretation of the provision. It ruled in line with the European legislator's preferences ${ }^{\mathrm{L}}$ that 'the wording of Article 3(9) of Directive 2005/29 merely allows Member States to adopt more stringent national rules in relation to financial services and does not enter into further detail. Accordingly, it does not impose any limit as regards how stringent national rules may be in that regard or lay down any criteria regarding the degree of complexity or risk which those services must involve in order to be covered by more stringent rules. Nor does it follow from the wording of that provision that the more restrictive national rules can cover only combined offers composed of a number of financial services or only combined offers of which the main component is the financial service'. ${ }^{\text {LI }}$

The Court's analysis of the free movement provisions in the TFEU also produced the same result: since financial services are, by nature, complex and entail specific risks with regard to which the consumer is not always sufficiently well informed, a combined offer of which one component is a financial service may well mislead consumers as to the true content and actual characteristics of the combination offered and, at the same time, deprive them of the opportunity of comparing the price and quality of that offer with other corresponding services from other economic operators. ${ }^{\text {LII }}$ Furthermore, and despite total harmonisation, the use of open norms in the prohibitions laid down in the UCPD allows room for nationally inspired applications. Take for instance the prohibition of misleading 
actions as an example: it prohibits commercial practices that contain false, or even factually correct information that, including the overall presentation, deceives or is likely to deceive the average consumer in relation to one or more of the elements specified in the provision, and causes or is likely to cause him to take a transactional decision that he would not have taken otherwise (see art. 6 (1) UPCD). References to the overall presentation of commercial practice and its impact on the purchase decision of a consumer entail a certain discretion for national courts; the exhaustive list of elements about which deception can take place allows for a certain discretion. The list for instance refers to deception about the 'main characteristics of the products' but proceeds with the wording 'such as', thus allowing national courts to expand the list of main characteristics.

The general scheme of the UCPD also allows some leeway for the national courts. Interpreting the unfair commercial practices of the black list annexed to the UCPD, the CJEU held in 4Finance ${ }^{\mathrm{LIII}}$ that 'a practice not covered by Annex I to Directive 2005/29 may nevertheless be prohibited where a specific and concrete assessment leads to the conclusion that it is unfair within the meaning of Articles 5 to 9 of that directive'. ${ }^{\text {LV }}$ In contrast, where a practice comes within the scope of the blacklisted provisions, the prohibition is absolute. In the case law of the CJEU a literal interpretation of the blacklisted unfair practices prevails.

For instance, in Purely Creative ${ }^{L V}$ the Court held that the commercial practice of informing a consumer that he has won a prize and obliging him, in order to receive that prize, to incur a cost of whatever kind, is in all circumstances prohibited. Moreover, it is not permissible to allow traders to make use of a multi-option scheme, unless at least one of the methods did not involve any payment by the consumer.

Such restrictive interpretation is legitimized by the CJEU on the basis of the high level of consumer protection pursued by the UCPD, and the precise function of the black list within the internal market. As to the first, the CJEU points out that unfair practice exploits the psychological effect caused by the announcement of the winning of a prize, in order to induce the consumer to make a choice which is not always rational, such as calling a premium rate telephone number to ask for information about the nature of the prize, travelling at great expense to collect an item of low-value crockery or paying the delivery costs of a book which he already has. Even when one of the methods would not involve any cost, the psychological exploitation of the consumer would remain the same. As 
concerns the internal market, the objective of legal certainty would not be achieved if traders were allowed to impose on the consumer costs which are 'de minimis' compared with the value of the prize. That would make it necessary to determine evaluation methods both for the costs and the prizes, and would also require such difficult evaluations to be carried out by national courts on a case-by-case basis, in order to prove that 'de minimis' element, which is precisely what Annex I to the directive sought to avoid by including that practice. $^{\text {LVI }}$

Moreover, the benchmark of the 'average consumer' referred to in the UCPD creates a certain flexibility, albeit that the CJEU has to a considerable extent handcuffed national judges, by stating that, in the case that the consumer was able to make informed choices, market deregulation prevailed over national regulatory protection (see more extensively: Straetmans 2016, 199-210). This case law concerning misleading practices will be briefly highlighted in subsection $\mathrm{B}$.

\subsection{Case law of the CJEU concerning misleading practices}

The CJEU has consistently held that the assessment of whether an appellation, brand name or advertising statement may be misleading must take into account the presumed expectations of an average consumer who is reasonably well informed and reasonably observant and circumspect. ${ }^{\text {LII }}$ This benchmark of the European average consumer has its origin in the prime consideration, taken from non-binding preliminary programmes for a consumer protection and information policy, that consumers should be enabled to make a choice in the market in full knowledge of the facts. ${ }^{\text {LVIII }}$ The emergence of this European consumer image was implicitly present in misleading practices cases like GB-Inno-BM, ${ }^{\text {LIX }}$ Yves Rocher ${ }^{\text {LX }}$ and Mars, ${ }^{\text {LXI }}$ and was subsequently consolidated in the Gut Springenbeide and Tusky case. ${ }^{\text {LXII }}$ It has since been confirmed in case law, and also more recently in legislation. ${ }^{\text {LXII }}$

With regard to labelling requirements, the CJEU emphasized that the rational consumer, whose purchasing decisions also depend on the composition of the products, will first read the list of ingredients. As a result the average consumer who is 'reasonably well informed and reasonably observant and circumspect' is not misled by the use of a term on the label if the seemingly misleading impression the term entails is contradicted by the list of ingredients that duly indicates the presence of all the ingredients in the product. ${ }^{\text {LXIV }}$ Hence, a comprehensive and correct list of ingredients on the packaging of a product may 
prevent a consumer's misleading impression derived from a term or depiction used on the packaging of the product. ${ }^{\mathrm{LXV}}$

Although the CJEU recognises that cases may exist where the requirement of an additional statement to the trade description is necessary in order to avoid any confusion on the part of consumers, it has consistently struck down additional national labelling requirements to that end. In Commission vs. Italy, ${ }^{\mathrm{LXVI}}$ for instance, the CJEU opposed Germany's prohibition of the marketing of hollandaise sauce or béarnaise sauce prepared from vegetable fats instead of butter and eggs in accordance with the recipe traditionally followed in Germany. The CJEU stated that 'for consumers who are heedful of the composition of a product, sufficient information is available by way of the list of ingredients which (...) must appear on the labelling. ${ }^{\text {LXVII }}$ In the same vein, the CJEU held in Darbo ${ }^{\text {LXVIII }}$ that mentioning 'naturrein' on the packaging of strawberry jam gave consumers no misleading impressions. It pointed out that an average consumer who is reasonably well informed and reasonably observant and circumspect could not be misled by the term 'naturally pure' used on the label simply because the jam contains pectin gelling agent whose presence is duly indicated on the list of its ingredients'. ${ }^{\text {LxIx }}$

In misleading advertising cases the CJEU also emphasized that the European average consumer has a duty to internalize the information which is disclosed to him in the market (for a more elaborated account of the developments in case law of the CJEU: Straetmans 1998, 355-408; Straetmans 2013, nrs. 100-101, 108-122, Weatherill 2013, 5-20). The Clinique $^{\mathrm{LXX}}$ case is illustrative of this point; the German Government sought to stop the use of the name 'Clinique' for cosmetic products, on the grounds that that name could mislead consumers into believing that the products in question had medicinal properties. The CJEU adequately countered the German objections. It stated 'that the range of cosmetic products manufactured by the Estée Lauder Company is sold in the Federal Republic of Germany exclusively in perfumeries and cosmetic departments of large stores, and therefore none of those products is available in pharmacies. It is not disputed that those products are presented as cosmetic products and not as medicinal products. It is not suggested that, apart from the name of the products, this presentation does not comply with the rules applicable to cosmetic products. Finally, according to the very wording of the question referred, those products are ordinarily marketed in other countries under the name 'Clinique' and the use of that name apparently does not mislead consumers'. ${ }^{\text {XXXI }}$ 
Hence the German prohibition did not appear to be necessary to satisfy the requirement of consumer protection and human health. The Court therefore added 'the clinical or medical connotations of the word 'Clinique' are not sufficient to make that word so misleading as to justify the probibition of its use on products marketed in the aforesaid circumstances' (own emphasis). ${ }^{\text {LXXII }}$

The importance of this last sentence cannot be overlooked. Even though the CJEU recognised that the possibility should not be excluded that German consumers may wrongfully infer from the product name that it has medicinal qualities, this is not sufficient to prohibit the use of that name as deceptive. The product is presented as a cosmetic product, its presentation complies with the specific labelling requirements laid down in European directives, and the product can only be bought outside pharmacies. This information should suffice to alert the European consumer and allows him to correct his initial wrongful inferences from the product name.

The bluntness of the CJEU in Clinique, and the CJEU's preference for the European average consumer as a standard for the assessment of misleading practices, has been criticised in consumer literature as majoritarianism (Weatherill 1999, 51-85). Some have argued that the concept of the average, confident consumer has a very weak and unreliable basis in Community law (Roth 2003, 944; Wilhemsson 2007, 243-268; Unberath 2007, 1251-1252). In the same vein, a common objection is that although information disclosure can contribute to the empowerment of consumers, it is often of very little help to vulnerable consumers when it comes to leading a self-determined life (Howells 2005, 360-372). This has even prompted some scholars to conclude that European consumer information policy leaves out the protection of the really weak, illiterate or poor consumer (Hondius 2006, 93; Heiderhoff 2000-7, 743).

In consequence, the CJEU somewhat mitigated the effect of its rulings in subsequent judgments. Thus, in Estée Lauder, ${ }^{\mathrm{LXXII}}$ whilst confirming the standard of the average consumer, the CJEU also held that in particular, it must be determined whether social, cultural or linguistic factors may justify the term "lifting", used in connection with a firming cream, as meaning something different to the German consumer as opposed to consumers in other Member States, or whether the instructions for the use of the product are in themselves sufficient to make it quite clear that its effects are short-lived, thus neutralising any conclusion to the contrary that might be derived from the word "lifting". Lxxiv 
However, the mitigating effect of the reference to particular social, cultural or linguistic factors was put immediately into perspective by the Court's consideration that 'at first sight, the average consumer - reasonably well informed and reasonably observant and circumspect - ought not to expect a cream whose name incorporates the term 'lifting' to produce enduring effects'. ${ }^{\text {LXVV }}$ The CJEU acted similarly in the Linhart and Biffl ${ }^{\mathrm{XXVI}}$ case, where it held that the mere statement 'dermatologically tested' or 'clinically tested' appearing on the packaging of soaps and hair products meant that the product was 'well tolerated or at least harmless when applied to the skin'. LXXVII

It follows from the foregoing that the European average consumer is depicted as someone who is well capable of processing information which is disclosed in the market. Moreover, the European average consumer has a duty to take advantage of this information, the release of which is not non-committal, especially when that information empowers him to correct his misleading impressions based on the product name, or other particulars of the product, or in advertising.

And yet, despite the preference for an average consumer tailored to the objectives of the internal market, recent developments in the CJEU's case law may reveal a changing approach towards the consumer's duty to internalize disclosed information, and perhaps also towards national courts' leeway to include national preferences in the assessment.

In the recent Teekanne case, ${ }^{\mathrm{LXXVIII}}$ the Court had to interpret the alleged misleading character of the mentions on the packaging of a fruit tea. That packaging comprised a number of elements of various sizes, colour and font, in particular (i) depictions of raspberries and vanilla flowers, (ii) the indications 'fruit tea with natural flavourings' and 'fruit tea with natural flavourings - raspberry-vanilla taste' and (iii) a seal with the indication 'only natural ingredients' inside a golden circle. The questions referred to the Court were not so much about whether information requirements stemming from the foodstuff labelling directive (Directive 2000/13/EC repealed by Regulation 1169/2011/EU) were complied with - the list of ingredients on the packaging correctly referred to 'natural flavourings with a taste of vanilla' and 'natural flavourings with a taste of raspberry, blackberries, strawberry, blueberry, elderberry' - but whether the depictions on the packaging of the fruit tea were of such a nature that they could mislead consumers with regard to the tea's content. In other words, does the labelling of a foodstuff and methods used for the labelling give the consumer the impression, by means of the appearance, 
description or pictorial representation of a particular ingredient, that that ingredient is present, even though it is not in fact present and this is apparent solely from the list of ingredients on the foodstuff's packaging?

Having regard to the settled case-law set out above, one would have expected the CJEU to rule that the list of ingredients expresses, in a manner free from doubt, the fact that the flavourings used are not obtained from vanilla and raspberries but only taste like them, and that correct and complete information provided by the list of ingredients on packaging constitutes sufficient grounds on which to rule out the existence of any misleading of consumers. As indicated above, consumers have a duty to internalize information which is disclosed to them in the market and on the products.

At first, the Court in Teekanne confirmed that it is apparent from the case-law that the Court has acknowledged that consumers whose purchasing decisions depend on the composition of the products in question will first read the list of ingredients, the display of which is required. ${ }^{\text {LxIx }}$ But then the CJEU surprisingly continued that 'the list of ingredients, even though correct and comprehensive, may in some situations not be capable of correcting sufficiently the (average reasonably well informed, and reasonably observant and circumspect) consumer's erroneous or misleading impression concerning the characteristics of a foodstuff that stems from the other items comprising its labelling' (own emphasis). ${ }^{\text {Lxxx }}$

In doing so, in the Teekanne case the CJEU recognised for the first time that correct and complete information provided by the list of ingredients on packaging, in accordance with the labelling of foodstuffs directive, may constitute misleading advertising. It follows that the display of the correct and comprehensive list of ingredients no longer rules out the possibility that the labelling has the capacity to mislead consumers. That would be the case for instance if some of the elements of which the labelling is composed are in practice misleading, erroneous, ambiguous, contradictory or incomprehensible. ${ }^{\text {LXXXI }}$ Indeed, the prime consideration of European labelling laws is that the consumer has correct, neutral and objective information that does not mislead him. ${ }^{\text {LXXXII }}$ The CJEU added that 'where the labelling of a foodstuff and methods used for the labelling, taken as a whole, give the impression that a particular ingredient is present in that foodstuff, even though that ingredient is not in fact present, such labelling is such as could mislead the purchaser as to the characteristics of the foodstuff (own emphasis). ${ }^{\text {LXxxIII }}$ 
Whether the consumer is actually being misled is for the referring court to examine. It must carry out an overall examination of the various items comprising the fruit tea's labelling in order to determine whether an average consumer may be misled as to the presence of raspberry and vanilla flower, or flavourings obtained from those ingredients. To further guide national judges, the CJEU in Teekanne pointed out that 'in order to assess the capacity of labelling to mislead, the national court must in essence take account of the presumed expectations, in light of that labelling, which an average consumer who is reasonably well informed, and reasonably observant and circumspect has, as to the origin, provenance, and quality associated with the foodstuff, the critical point being that the consumer must not be misled and must not be induced to believe, incorrectly, that the product has an origin, provenance or quality which are other than genuine'. Lxxxiv Furthermore, the national court must in particular take into account 'the words and depictions used as well as the location, size, colour, font, language, syntax and punctuation of the various elements on the fruit tea's packaging. ${ }^{\text {Lxxxv }}$

These developments in respect of labelling requirements demonstrate that the CJEU is increasingly aware of national critiques on how the benchmark of the average consumer is applied in cases of deception. It reduces the consumer's responsibility to process information, as well as his duty to internalize mandated or voluntary disclosures when taking purchase decisions. ${ }^{\text {LXxxvI }}$

This case law exerts an influence on how the prohibition of misleading commercial practices under the UCPD is to be applied, and allows national judges to mitigate, to a certain extent, the outcomes of the assessment in the light of the European average consumer benchmark. The guidelines for the assessment of the misleading character proposed by the CJEU already coincide with the assessment criteria of misleading commercial practices provided for by the UCPD. There too, the national court is required to carry out a global, synthetic assessment of commercial practice taking into account all relevant circumstances of the case in view of assessing the capacity of a commercial practice to mislead consumers. The wording of the prohibition to mislead consumers in the $\mathrm{UCPD}$, highlighted above, is also flexible enough to allow national judges to make an assessment, provided that the (correct or wrong) information negatively affects the purchase decision of the consumer. This has been confirmed recently in the Team4Travel case $^{\text {LXXXVII }}$ where the CJEU held that the misleading nature of a commercial practice 
derives solely from the fact that it is untruthful in as much as it contains false information or that, generally, it is likely to deceive the average consumer in relation to, inter alia, the nature or main characteristics of a product or a service and that, therefore, it is likely to cause that consumer to take a 'transactional' decision that he would not have taken if there had been no such practice'.

Also, the recent Canal Digital Danmark ${ }^{\mathrm{LXXXVIII}}$ case seems to confirm the approach taken in Teekanne. The case concerned Canal Digital's price advertising campaign for TV subscriptions on television and on the internet. The CJEU held that when the price of a product is divided into several components, one of which is particularly emphasised in the marketing, while the other is completely omitted or is presented less conspicuously, 'an assessment should be made, in particular, whether that presentation is likely to lead to a mistaken perception of the overall offer. ${ }^{\text {LXxxIX }}$ This will be the case if the average consumer is likely to have the mistaken impression that he is offered a particularly advantageous price, due to the fact that he could believe, wrongly, that he only had to pay the emphasised component of the price' ${ }^{\mathrm{XC}}$ An advertisement will be all the more misleading if the omitted, or less visible, component of the price represents a significant part of the total price that the consumer is required to pay. The fact that the total price was mentioned in the initial advertising or could be retrieved on the website of the advertiser does not shield the trader from the application of the prohibition of misleading actions. The objective of a high level of consumer protection set forth in the UCPD serves as a correcting factor for literal interpretations of the Directive's provisions with adverse effects on consumer protection.

Thus, in a striking parallel with Teekanne, the CJEU emphasised in Canal Digital Danmark that an average consumer who is provided with correct and comprehensive information in advertisements, nevertheless may have a mistaken perception of the offer due to the presentation of that information taken as a whole. The Court does so without renouncing that the average consumer must serve as a benchmark for the assessment of misleading practices (in labelling, in advertising, etc.). That way, the Court seems to confirm the stance it has developed with regard to misleading packaging of products. Despite the absence of any reference to Teekanne, it may in our view be deduced from the approach taken in Canal Digital Danmark that a similar correction ${ }^{\mathrm{XCI}}$ to the general rule 
applies in both subdomains of misleading practices. The CJEU has managed to bridge the case law in both domains of unfair marketing law.

It follows that even in the case where a trader satisfies the information requirements imposed by the law, this does not rule out that the information may be presented in such a manner that the average consumer remains misled, notwithstanding the correct and comprehensive information he received. This characterization, by the national judge, must be based on an overall assessment of the case. As the CJEU pointed out in Teekanne, in some circumstances correct and comprehensive information may no longer be capable of correcting the consumer's erroneous or misleading impressions based on other informational elements.

\subsection{National case law}

Notwithstanding the strong adherence to the European standard of an average consumer of national courts, national traditional standards continue to play an important role in the assessment of law provisions.

Within Europe, the UK takes, for instance, a particular place. The average consumer has become the benchmark for the law of unfair commercial practices, but even before the UCPD was adopted the UK traditionally adopted a robust approach; demanding that consumers make a realistic interpretation of advertising. We have also seen that the UK is comfortable with the average consumer context, and in the UK Consumer Rights Act 2015 uses the average consumer for one additional particular point concerning unfair terms control: to determine whether a term specifying the main subject matter of the contract, or assessment of the price (see also supra), is sufficiently prominent to be excluded from the Act's assessment of fairness. ${ }^{\text {XCII }}$

The most prominent example of the leeway granted to the Member States is Finland where psychologically inspired assessments by the Market Court remodel the average consumer, stating for instance that the value of the giveaway should not be used to distract a consumer from the price of the main product, and that reporting prices to consumers in an inconsistent way may be considered to be inappropriate, or otherwise unfair conduct, in marketing consumer goods. ${ }^{\mathrm{XCII}}$ It follows that the general benchmark for the Finnish national consumer legislation remains a weaker, less rational consumer. In the same vein, Greek courts rely on a relatively well informed but inexperienced consumer, halfway 
between a careful, suspicious or observant person and a gullible, completely indifferent or careless person. ${ }^{\mathrm{XCIV}}$

Irish courts also struggle with the application of the average consumer, especially in advertising cases. In the Aldi decision, the Court of Appeal avoided an overly paternalistic approach to the average consumer, stating that ' $[\mathrm{t}]$ he notional consumer has common sense' and that 'shoppers have to be given some credit for intelligence and appreciation of common marketing practice'. ${ }^{\mathrm{XCV}}$ In this case Aldi objected to a comparative advertising campaign by the Dunnes chain of supermarkets, in which shelf-edge labels compared Dunnes's and Aldi's prices for 262 separate products. Aldi claimed this was misleading, particularly in relation to certain products, since Dunnes compared the price of their own brand tomato ketchup with Aldi's even though Aldi's ketchup has more tomato content, and compared its own-brand products when the Aldi products carried quality assurance marks (Kelly 2018). The High Court stated that comparisons are misleading if not all material and relevant features of the products are set out in the comparative advertising. However, the Court of Appeal rejected the assumption that it would inevitably be misleading not to provide full details of the compared products: 'a comparison of products meeting the same needs or intended for the same purpose may be compared by reference only to price, always assuming that the comparison is not outlawed as being misleading, ${ }^{\mathrm{XCVI}}$ The misleading character of the advert had to be based on an independent finding of a misleading practice, and not merely based on the fact that the advertisement had failed to set out all the features of the products. The Court of Appeal continued that a decision such as misleading practice should not be lightly found. In this case the intention was comparison, not deceit and neither was there a case of deliberately seeking to mislead consumers. ${ }^{\text {XCVII }}$ The Court of Appeal thus concluded that the average consumer was well capable of understanding price comparisons of that type and would not be misled either by general slogans such as 'lower price guarantee' and 'always better value'. XCVIII

However, in the McCambridge case ${ }^{\mathrm{XcIx}}$ the Supreme Court seem to depart from the stricter European standard in favour of, according to Kelly, a perhaps more realistic view of a consumer, stating that 'even ordinary reasonable prudent consumers do not, in fact, frequently carry out a detailed examination of the product [bread] at the time when they take the bread from the supermarket shelf and place it in the supermarket trolley' (Kelly 2018). This case concerned a common law action for passing off 'which requires that the 
plaintiff has a "goodwill" or reputation in his business, that consumers are likely to be misled into buying the goods / services of the defendant, and that the plaintiff is therefore likely to suffer damage' (Kelly, 2018). Although there was some evidence that if the consumer actually looked at the packaging and 'get up' of the defendant's soda bread they would not confuse it with that of the plaintiff, the Court held that one bakery had passed off its soda bread as that of the rival bakery, as there was the potential for confusion if consumers put in into their shopping trolley without properly looking at it. The Court emphasised 'the phenomenon of fast moving consumer goods displayed on the supermarket shelf, ${ }^{\mathrm{C}}$ and stated that 'even ordinary reasonable prudent consumers do not, in fact, frequently carry out a detailed examination of the product at the time when they take the bread from the supermarket shelf and place it in the supermarket trolley' (Kelly 2018).

Polish courts experienced similar difficulties in advertising cases for which courts developed a formalized, two-step test. First, the targeted audience was determined on the basis of the type of the advertised product or service and, second, the medium used for the advertisement is taken into account. ${ }^{\mathrm{CI}}$ Assessments by courts were made in that particular order and may sometimes, in contrast with the Irish evolution, lead to weaker protection. In a 2014 judgment concerning the sales of tickets to UEFA EURO 2012 football games, the Polish Supreme Court held that a term included in the standard conditions of business, according to which, in case of a discrepancy between English and Polish language versions of the conditions, the English version should prevail, was not unlawful within the meaning of Article $385^{1}$ of the Civil Code. This was due to the fact that contested standard terms only applied to the online sales channel and therefore were addressed at a group of consumers who were more technology-savvy, active, well-informed, cautious, attentive and used to standard terms being drafted in English". ${ }^{\text {.II }}$

\section{Conclusion}

We have pointed out above that legal scholars have criticised the CJEU's inclination to favour the internal market approach, to the detriment of national regulatory autonomy. It was felt that, especially in the eighties and nineties, CJEU case law disregarded national 
preferences, and endowed average consumers with characteristics that were far from realistic.

However, it must be noted that the CJEU should not be criticised for straining the limits of judicial interpretation, as it has often the difficult task to draw lines on the basis of legal rules that leave open a number of crucial questions. The abovementioned analysis of the Court's interpretation of provisions of the UCTD and UCPD further underscores this.

It follows that the Court's case law is legitimate, exercising its role within the EU's constitutional legal order of states and peoples. Even strong opponents, in terms of the CJEU's 'legitimacy' of rulings, recognise that the role the CJEU has played in the process of Union building and European integration has been second to none (Weiler 2015, 253). ${ }^{\text {CIII }}$ In the same vein Weatherill points out that most of 'the Court's embrace of a circumloquacious statement of the result rather than a reasoning for arriving at it is the result of the calculatedly imprecise concept of the internal market loaded into the Treaty' (Weatherill $2015,108)$. Snell, in his examination of the legitimacy of free movement case law, also concludes that despite the legitimacy of the case law of the CJEU having been weakened by insufficiently reasoned judgments, it may be the least bad option (Snell 2015, 124-126). ${ }^{\text {CIV }}$

This analysis demonstrates that with regard to both the UCTD and the UCPD the CJEU took on a gap-filling role. In particular, in its case law relating to the transparency requirement in the UCTD, the CJEU gradually laid out the understandings of extensiveness in the requirement of intelligibility. This involved developing a more sophisticated model of the average consumer. Under pressure of national and behavioural economists' critiques on how the benchmark of the average consumer is applied in cases of deception, the CJEU showed itself prepared to reduce the consumer's responsibility to process information and to mitigate the consumer's duty to internalize mandated or voluntary disclosures when taking purchase decisions.

Within the paradigms debate, it comes as no surprise that now that the internal market has come of age, attention has shifted to the complementary paradigm of consumer protection. When the internal market economy is thriving, adjustments can be made to bring the internal market paradigm more in line with the high level of consumer protection that both the UCTD and UCPD intend to ensure. In this context of a more mature legal order, the CJEU is enabled, depending on the circumstances, in its display of greater deference to the preferences of the EU legislator, or to those of the Member States. It 
nudges Member States towards a more convergent interpretation, whilst allowing room for national variations in application.

The analysis of national case law relating to unfair contract terms and unfair commercial practices illustrates that national traditional standards continue to play an important role in the assessment of law provisions. This may be seen as self-evident in the presence of a minimum harmonisation directive like the UCTD, which automatically implies a broad discretion for the Member States. But with regard to the maximum harmonisation brought about by the UCPD, the use of general concepts like the average consumer, as interpreted by the CJEU, also allows room for national divergent applications.

It is, however, interesting to see that irrespective of the underlying level of harmonisation the CJEU, backed by the European legislator's intention to ensure a high level of consumer protection, is gradually depicting the European average consumer with more realistic features. Here, the case law of the CJEU fulfils a bridging function between the labelling requirements in the Foodstuff Regulation, the transparency requirements in the UCTD, and the informed decision requirements in the UCPD. In these three domains the CJEU recognises that the level of attention of the consumer may be suboptimal, even in the presence of comprehensive and correct information. ${ }^{\mathrm{CV}}$ Yet, the impact of the Court's case law in these domains is quite different. In the context of unfair terms control the CJEU imposes a stricter standard on businesses, to take account of the limited abilities of the average consumer. A similar approach with regard to unfair commercial practices mitigates the existing standard as understood from free movement case law. In the domain of foodstuff labelling the Court's approach is in line with the very detailed rules laid down by the European Legislator. In all three cases, the CJEU's interpretation contributes to the high level of consumer protection set forth by the European legislator.

The CJEU's approach contributes to more convergence in consumer protection throughout the EU. Yet, in terms of legitimacy, it must be noted that the CJEU in all cases has maintained a clear line between interpretation and application. This is best illustrated with RWE Vertrieb v Verbraucherzentrale Nordrbein-Westfalen EV $V^{\mathrm{CVI}}$ in which case the Court 'recalled that ultimately it is not for the Court but for the national court to determine in each particular case whether that is so. The jurisdiction of the Court extends to the interpretation of the provisions of those directives and to the criteria which the national 
court may or must apply when examining a contractual term in the light of those provisions, bearing in mind that it is for that court to determine, in the light of those criteria, whether a particular contractual term is actually unfair in the circumstances of the case.' ${ }^{\text {CVII }}$

The particular constitutional legal order in which the CJEU operates only allows for a process whereby the contours of a more coherent European consumer protection policy are gradually revealed. In the absence of sufficient legislative guidance at the European and national level, national courts may be increasingly inspired by the case law of the CJEU in an effort to establish the clearly desirable common expectations. Those who believe that uniformity can be achieved in practice overnight by simply adopting a common maximum norm appear over-optimistic.

\footnotetext{
* Geraint Howells is Dean and Chair Professor of Commercial Law at City University of Hong Kong. Gert Straetmans is Full Professor of European Economic and Commercial Law at the University of Antwerp, Research Group Business \& Law. He is also substitute judge at the Court of Appeal Antwerp.

I In its original version, the EC Treaty commanded the Court of Justice to ensure that in the interpretation and application of the Treaties the law is observed, but did not define 'the law'. 'In order to honour that constitutional mandate in a self-referential and, in that sense, autonomous legal order, the ECJ could not limit itself to a formalistic understanding of the rule of law. Accordingly, it had no choice but to complete the constitutional lacunae left by the authors of the Treaties. In so doing, (...) EU law could not break away from the constitutional traditions of the Member States'.

II CJEU 14 March 2013, Case C-415/11, Aqiz v Caixa d'Estalvis de Catalunya, Tarragona $i$ Manresa (Catalunyacaixa), ECLI:EU:C:2013:164, para 69.

III See Aziz, op cit.

IV Wilhemsson has labelled this the "possible agreement test" (Howells forthcoming [2018]) at 148

v Aziz.

VI This is backed up by a rule of interpretation which states the meaning most favourable to the consumer should prevail (although this does not apply in collective actions as it might save terms that were harmful to the consumer): art. 5 .

VII Art. 5. Injunction actions are also possible, in which case this interpretative rule does not apply: art 5 in fine and art. 7 (2). This is so as not to protect terms that are potentially unfair to consumers.

VIII CJEU 3 April 2014, Case C-342/13, Katalin Sebestyén v Zsolt Csaba Kövári, OTP Bank. Nyrt., OTP Faktoring Követeléskezelö Zrt, Raiffeisen Bank Zrt, ECLI:EU:C:2014:1857.

IX CJEU 21 November 2002, Case C-473/00, Cofidis SA v Jean-Louis Fredout, ECLI:EU:C:2002:705.

x CJEU 14 March 2013, Case C-415/11, Mohamed Ažiz v Caixa d'Estalvis de Catalunya, Tarragona i Manresa (Catalunyacaixa), ECLI:EU:C:2013:164, para 76.

XI CJEU 27 June 2000, Joined Cases C-240/98 to C-244/98, Océano Grupo Editorial SA v Roció Murciano Quintero and Salvat Editores SA v José M. Sánchez. Alcón Prades, José Luis Copano Badillo, Mohammed Berroane and Emilio Viñas Feliu, ECLI:EU:C:2000:346 ; CJEU 6 October 2009, Case C-40/08, Asturcom Telecomunicaciones SL $v$ Cristina Rodríguez Nogueira, ECLI:EU:C:2009:615 and CJEU 26 October 2006, Case C-168/05, Elisa María Mostaza Claro v Centro Móvil Milenium SL, ECLI:EU:C:2006:675.

XII CJEU 9 November 2010, Case C-137/08, VB Penzugyi Liz̨ing ZRT v Ferenc Schneider, ECLI:EU:C:2010:659.

XIII CJEU 27 June 2000, Joined Cases C-240/98 to C-244/98, Océano Grupo Editorial SA v Roció Murciano Quintero and Salvat Editores SA v José M. Sánchez. Alcón Prades, José Luis Copano Badillo, Mohammed Berroane and Emilio Viñas Feliu, ECLI:EU:C:2000:346.

XIV CJEU 1 April 2004, Case C-237/02, Freiburger Kommunalbauten GmbH Bangesellschaft \& Co. KG v Hofstetter, ECLI:EU:C:2004:209.

xv CJEU 1 April 2004, Case C-237/02, Freiburger Kommunalbauten GmbH Baugesellschaft \& Co. KG v Ludger
} 
Hofstetter and Ulrike Hofstetter, ECLI:EU:C:2004:209.

xvI Aziq, para 67.

XVII Ibid., para 68.

XVIII Ibid., para 69.

XIX CJEU 30 April 2014, Case-26/13, Arpád Kásler and Hajnalka Káslerné Rábai v OTP Jelálogbank Zrt, ECLI:EU:C:2014:282.

xx Ibid., para 49-50.

xxI Ibid., para 23.

XXII CJEU 26 April 2012, Case C-472/10, Nemzeti Fogyasztóvédelmi Hatóság v Invitel Távközlési Zrt, ECLI:EU:C:2012:242.

XXIII It is unclear whether the case was about the power to vary the contract by including these expenses or the fact the new term failed to specify the method of calculating expenses.

XXIv CJEU 26 April 2012, Case C-472/10, Nemzeti Fogyasztóvédelmi Hatóság v Invitel Távközlési Zrt, ECLI:EU:C:2012:242, para 28.

xxvCJEU 21 March 2013, Case C-92/11, RWE Vertrieb AG tegen Verbraucherzentrale Nordrhein-Westfalen eV, ECLI:EU:C:2013:180.

xxvi CJEU 30 April 2014, Case-26/13, Arpád Kásler and Hajnalka Káslerné Rábai v OTP Jelzálogbank Zrt, ECLI:EU:C:2014:282.

xxviI Compare CJEU 26 February 2015, Case C-143/13, Matei, ECLI:EU:C:2015:127, paras 73-77.

xxvIII CJEU 23 April 2015, Case C-96/14, Jean-Claude V an Hove v. CNP Assurances SA, ECLI:EU:C:2015:262

Xxix See para 48 A similar mitigating approach can be seen in CJEU 3 April 2014, Case C-342/13, Katalin Sebestyén, ECLI:EU:C:2014:1857, para 34, where the Court held: "even assuming that the general information the consumer receives before concluding a contract satisfies the requirement under Article 5 that it be plain and intelligible, that fact alone cannot rule out the unfairness of a clause providing for the exclusive competence of a single arbitration tribunal".

xxx CJEU 16 November 2010, Case C-76/10, Pohotovost, ECLI:EU:C:2010:685.

xxxi CJEU 9 July 2015, Case C-348/14, Maria Bucura, ECLI:EU:C:2015:447.

xxxiI CJEU 16 November 2010, Case C-76/10, Pohotovost, ECLI:EU:C:2010:685, para 71.

XxxIII See Lords Neuberger and Sumption in Cavendish Square Holding BV v Makdessi; ParkingEye Ltd v Beavis [2015] UKSC 67, 2015] 3 WLR 1373, at para 105. Lord Carnwath agreed.

Xxxiv [2001] UKHL 52, [2002] 1 A.C. 481.

xxxv [2009] All ER (D) 271 (Nov).

xxxvi The German Supreme Court assessed whether an overdraft was fair without even considering whether it was subject to assessment: BGH 21 October 1997, BGHZ 137, 43, NJW 1998, 309. See discussion in Law Commission, Unfair Terms in Consumer Contracts: A New Approach? (2012) para 7.56-61 and Annex A.

xxxvil CJEU 30 April 2014, Case-26/13, Arpád Kásler and Hajnalka Káslerné Rábai v OTP Jelzálogbank. Zrt, ECLI:EU:C:2014:282.

xxxvIII Cavendish Square Holding BV v Makdessi; ParkingEye Ltd v Beavis [2015] UKSC 67, [2015] 3 WLR 1373.

xxxix Ibid., para 309.

XL According to the Polish Supreme Court the lack of transparency of a standard term can in itself constitute an unfair term, irrespective of whether it contributes to a significant imbalance of the parties' rights and obligations to the detriment of the consumer. See Judgment of the Supreme Court in case I CSK 72/15 (n 27).

XLI CJEU 30 April 2014, Case-26/13, Árpád Kásler and Hajnalka Káslerné Rábai v OTP Jelzálogbank Zrt, ECLI:EU:C:2014:282. In line with the Arpad Kasler-case of the ECJ, the consumer must be in a position to understand all the advantages and drawbacks of the contract terms used so that he is fully aware of the exact legal and economic reach of the terms and can make an informed choice.

XLII See e.g. Vred. Grâce-Hollogne 25 May 2012, JLMB 2012, 438.

XLIIISee Luik 27 March 2012, For. Ass. 2013, 137, annotation A. Cruquenaire. The term was worded as follows : "La présente assurance a pour objet de garantir l'assuré contre le risque de décès par accident, sauf celui expressément exclu par article III. La couverture vaut dans le monde entier. Par accident, on entend tout événement provenant de l'action soudaine et fortuite d'une cause extérieure étrangère à la volonté de l'assuré".

XLIV See Brussels 3 May 2002, DCCR 2003, 53, annotation E. Terryn.

XLV See e.g. CJEU 23 April 2009, Joined cases C-261/07 and C-299/07, VTB-VAB and Galatea, 
ECLI:EU:C:2009:244.

XLVI See CJEU 14 January 2010, Case C-304/08, Plus Warenhandelsgesellschaft, ECLI:EU:C:2010:12.

XLVII See CJEU 23 April 2009, Joined cases C-261/07 and C-299/07, VTB-VAB and Galatea, ECLI:EU:C:2009:244, para 52.

XLVIII Note that the CJEU is very strict in not allowing national laws to be justified on consumer protection grounds if they are advanced to conceal purely economic reasons. See e.g. CJEU 13 January 2000, C-254/98, Schutzverband gegen unlauteren Wettbewerb v TK-Heimdienst Sass GmbH., ECLI:EU:C:2000:12, para 33 and CJEU 18 September 2003, Case C-416/00, Tommaso Morellato v. Comune di Padova, ECLI:EU:C:2003:475, para 40.

XLIx CJEU 18 July 2013, Case C-265/12, Citroën Belux, ECLI:EU:C:2013:498.

L One of the objectives of the UCPD is to ensure a high level of consumer protection.

LI CJEU 18 July 2013, Case C-265/12, Citroën Belux, ECLI:EU:C:2013:498, para 25. The intention of the EU legislature is to leave it to the Member States themselves to assess how restrictive they wish to make those measures and to allow them freedom of action in that connection, enabling them to go so far as to prohibit certain arrangements.

LII See more in detail, CJEU 18 July 2013, Case C-265/12, Citroën Belux, ECLI:EU:C:2013:498, para 39.

LIII CJEU 3 April 2014, Case C-515/12, 4Finance, ECLI:EU:C:2014:211.

LIV CJEU 3 April 2014, Case C-515/12, 4Finance, ECLI:EU:C:2014:211, para 32. In the present case, the practice fell foul of the prohibition of pyramid promotional schemes, but could be combined with a misleading practice severable from the pyramid promotional scheme.

LV CJEU 18 October 2012, Case C-428/11, Purely Creative, ECLI:EU:C:2012:651.

LVI Ibid., paras 46-47.

LVII See in particular, CJEU 28 January 1999, Case C-303/97, Sektkellerei Kessler, ECLI:EU:C:1999:35, para. 36. Thereby, the CJEU was not particularly inspired by human information processing models taken from other disciplines. See for example the Limited Capacity Model of Mediated Message Processing and the LC4MP developed by Lang and find more about this model in the contribution of Mangold to this book.

LVIII CJEU 7 March 1990, Case C-362/88, GB-Inno-BM, ECLI:EU:C:1990:102, para. 17: 'a prohibition against importing certain products into a Member State is contrary to (the provisions relating to free movement of goods) where the aim of such a probibition may be attained by appropriate labelling of the products concerned which would provide the consumer with the information he needs and enable bim to make bis choice in full knowledge of the facts' (own emphasis).

LIX See CJEU 7 March 1990, Case C-362/88, GB-Inno-BM, ECLI:EU:C:1990:102. The ECJ agreed with the European Commission that any normally aware consumer knows that annual sales take place only twice a year so that the 'European' consumers would not be misled by information on temporary price reductions.

LX CJEU 18 May 1993, Case C-126/91, Yves Rocher, ECLI:EU:C:1993:191. The Court held that the prohibition on 'eye-catching' advertising was disproportionate: it also prohibits correct advertising that is eye catching.

LXI CJEU 6 July 1995, Case C-470/93, Mars, ECLI:EU:C:1995:224, para 24. The CJEU held that 'reasonably circumspect consumers may be deemed to know that there is not necessarily a link between the size of publicity markings relating to an increase in a product's quantity and the size of that increase'.

LXII CJEU 16 July 1998, Case C-210/96, Gut Springenheide and Tusky, ECLI:EU:C:1998:369, para. 31.

LXIII See Directive 2005/29/EC on unfair commercial practices (UCPD) and Directive 2011/83/EU on consumer rights (CRD).

LXIV See to that effect, e.g. CJEU 9 February 1999, Case C-383/97, Van der Laan, ECLI:EU:C:1999:64, para 37.

LXV See e.g. CJEU 10 September 2009, Case C-446/07, Severi, ECLI:EU:C:2009:530, para 61 on the question whether the designation of a foodstuff, 'Salame tipo Felino', which is evocative of a place and which is not registered as a PDO or PGI may be legitimately used by producers who use it uninterruptedly for a considerable period and in good faith, is misleading. "It is clear from the Court's case law that, in order to assess the capacity to mislead of a description to be found on a label, the national court must in essence take account of the presumed expectations, in light of that description, of an average consumer who is reasonably well informed, and reasonably observant and circumspect, as to the origin, provenance, and quality associated with the foodstuff, the critical point being that the consumer must not be misled and must not be induced to believe, incorrectly, that the product has an origin, provenance or quality which are other than genuine."

LXVI CJEU 25 November 2010, Case C-47/09, Commission vs. Italy, ECLI:EU:C:2010:714.

LXVII Ibid., para 36.

LXVIII CJEU 4 April 2000, Case C-465/98, Darbo, ECLI:EU:C:2000:184. 


\author{
LXIX Ibid., para 22. \\ LXX CJEU 2 February 1994, Case C-315/92, Clinique, ECLI:EU:C:1994:34. \\ LXxi Ibid., para 21. \\ LXXII Ibid., para 23. \\ LXXIII CJEU 13 January 2000, Case C-220/98, Estée Lauder Cosmetics vs. Lancaster Group, ECLI:EU:C:2000:8. \\ LXXIV Ibid., para 29. According to the German Government the use of the term 'lifting' for a firming cream \\ may mislead consumers as to the duration of the product's effects, because it gives purchasers the impression \\ that use of the product will obtain results which, above all in terms of their lasting effects, are identical or \\ comparable to surgical lifting. \\ LXXv CJEU 13 January 2000, Case C-220/98, Estée Lauder Cosmetics vs. Lancaster Group, ECLI:EU:C:2000:8, \\ para 30. \\ LXXVI CJEU 24 October 2002, Case C-99/01, Linhart and Biffl, ECLI:EU:C:2002:618. \\ LXXVII Ibid., para 32. \\ LXXVIII CJEU 4 June 2015, Case C-195/14, Bundesverband der Verbraucherzentralen e. a. vs. Teekanne GmbH, \\ ECLI:EU:C:2015:361. \\ LXxix Ibid., para 37. \\ LXxx Ibid., para 40. \\ LXxxi Ibid., para 41. \\ LXXXII See more in particular paragraphs 30-34 of the case. \\ LXXXIII Ibid., para 41. \\ Lxxxiv Ibid., para 36. \\ Lxxxv Ibid., para 43.
}

LXXXVI Also in the domain of unfair contract terms the CJEU showed itself prepared to reduce the impact on the (un)fair character of contract clauses of even extensive pre-contractual information, see CJEU 3 April 2014, Case C-342/13, Katalin Sebestyén v Zsolt Csaba Kövári, OTP Bank. Nyrt., OTP Faktoring Követeléskezelón Zrt, Raiffeisen Bank Zrt, ECLI:EU:C:2014:1857. The CJEU first confirmed the fundamental importance of precontractual information for the consumer's decision to be bound by the conditions drafted in advance by the seller or supplier. But instead of connecting immediate consequences for consumers to this voluntary disclosure by the trader, the ECJ was prepared to mitigate its impact on consumers, pointing out that "even assuming that the general information the consumer receives before concluding a contract satisfies the requirement under Article 5 that it be plain and intelligible, that fact alone cannot rule out the unfairness of a clause such as that at issue (red.: arbitration clause) in the main proceedings"(own emphasis). The high level of consumer protection set forth by the Unfair Contract Terms Directive must also have played a role in the ECJ's decision.

LXXXvII CJEU 19 September 2013, Case C-435/11, CHS Tour Services vs. Team4-Travel, ECLI:EU:C:2013:574.

LXxxviII CJEU 26 October 2016, Case C-611/14, Canal Digital Danmark, ECLI:EU:C:2016:800.

LXxxix Ibid., para 43.

xC Ibid.; para 44.

XCI Namely that even in the presence of complete and correct information deception of an average consumer can take place. (See already on this point prior to the Canal Digital Danmark case, (Straetmans, 2017, 102103).

xCII See UK Consumer Rights Act 2015: 'A term is prominent if it is brought to the consumer's attention in such a way that an average consumer would be aware of it'.

xCIII See Peltonen - Määttä, 2015, 88 and Market Court decision MAO 445/09.

xCIV See Athens Multi-Member Court of First Instance decisions, Armenopoulos 2004, 562 and further on this subject Delouka-Inglesi 2015, 41-87.

xCV Aldi Stores (Ireland) Limited and Aldi GMBH \& Co KG v Dunnes Stores, [2017] IECA 116, at paras 104 and 105.

XCVI [2017] IECA 116, para 30.

XCVII At this point Kelly in her contribution rightly points out that the UCPD prohibits misleading commercial practices irrespective of the trader's intentions to or not to mislead. Misleading practices is a strict liability offence.

XCVIII 'It seems to me that no sensible person could be misled by the use of general slogans that are the commonplace stuff of most advertising. [...] I think that shoppers have to be given some credit for intelligence and appreciation of common marketing practices. A lawyer's exegesis of the words used is wholly 
inappropriate and it would correctly be brushed aside as unworldly and unrealistic by any average shopper. In my view, the proposition accepted and adopted by the trial judge in this regard is, with respect, unrealistic and inconsistent with the attitude to be ascribed to a reasonably well-informed and circumspect shopper'. xcIx McCambridge Ltd v Joseph Brennan Bakeries [2013] 1 ILRM 369

C [2013] 1 ILRM 369, para 43.

CI See judgment of the Polish Supreme Court of 2 October 2007in case II CSK 289/07.

CII Judgment of the Polish Supreme Court in case I CSK 555/13 (n 27). See also European Commission, 'Fitness Check of EU Consumer Law', Brussels, 2017, 888.

CIII But he also warns: 'It is not simply that it has no major legitimacy problems in the big sense I have discarded at the outset' (238) that you cannot find 'structural issues which potentially compromise the institutional authority of the Court and the authoritativeness of its jurisprudence' (251).

CIV Yet, Snell emphasizes that the Court needs to ensure that it does not interfere excessively with national economic models.

CV See Teekanne, cited above, with regard to labelling of foodstuffs, Canal Digital, also cited above, concerning misleading practices and Katalin Sebestyén and Van Hove, both also cited above, with respect to the intelligibility of contract terms.

CVI CJEU 21 March 2013, Case C-92/11, RWE Vertrieb AG tegen Verbraucherzentrale Nordrhein-Westfalen eV, ECLI:EU:C:2013:180.

CVII Ibid., para 48. Within the framework of the prejudicial procedure the power of the CJEU is limited to giving preliminary rulings concerning the validity and interpretation of acts of the institutions of the Community, including directives (see Art. 267 TFEU).

\section{References}

- Beale Hugh, 1995, 'Legislative Control of Fairness: The Directive on Unfair Terms in Consumer Contracts', in Beatson Jack and Friedmann Daniel, Good Faith and Fault in Contract Law, Oxford University Press, Oxford.

- Brandner Hans Erich and Ulmer Peter, 1991, 'The Community Directive on Unfair Terms in Consumer Contracts: Some Critical Remarks on the Proposal Submitted by the EC Commission', Common Market Law Review, XXVIII(3): 647-662.

- Brownsword Roger, 1994, 'Two concepts of Good Faith', Journal of Contract Law, VII: 197-206.

- Dellios George, 2015, 'Article 2', in Alexandridou Elisa (ed), Greek and European Consumer Law, 2 ${ }^{\text {nd }}$ ed., Nomiki Vivkliothiki, Athens, 88-169.

- Delouka-Inglesi Cornelia, 'Article 9', in Alexandridou Elisa(ed), 2015, Greek and European Consumer Law, $2^{\text {nd }}$ ed., Nomiki Vivliothiki, Athens, 554-650.

- Farnsworth Allan, 1962, 'Good Faith Performance and Commercial Reasonableness Under the Uniform Commercial Code’, University of Chicago Law Review, XXX(4): 666-679.

- Giorgianni Michaela, 2009, Principi generali sui contratti e tutela dei consumatori in Italia e Germania, Saggi di diritto comemrciale, Giuffrè, Milano.

- Heiderhoff Bettina and Kenny Mel, 2007, 'The Commission's 2007 Green Paper on the Consumer Acquis: deliberate deliberation?', European Law Review, XXXV(5): 740-751.

- Hondius Ewoud, 2006, 'The notion of consumer: European Union versus Member States', Sydney Law Review, XXVIII(1): 89-98.

- Howells Geraint, 2005, 'The scope of European consumer law', European review of contract law, I(3): 360372.

- Howells Geraint, forthcoming, “The European Union's influence on English consumer contract law”, George Washington University Law Review.

- Howells Geraint, Twigg-Flesner Christian and Wilhelmsson Thomas, 2017, Rethinking EU Consumer Law, Routledge, London.

- Howells Geraint and Wilhelmsson Thomas, 1997, EC Consumer Law, Ashgate, Farnham.

- Illdiko Sik-Simon Rita, 2017, Study to support the Fitness Check of EU Consumer Law - Country Report Czech Republic, Prague, [SS92]. 
- $\quad$ Kelly Ciona, forthcoming 2018, Information/Disinformation of consumers including negotiation - Irish report, in Straetmans Gert (ed.), Information/Disinformation of consumers including negotiation, Springer, Ius Comparatum Global Studies in Comparative Law.

- Lenaerts Koen, 2015, 'The Court's Outer and Inner Selves: Exploring the External and Internal legitimacy of the European Court of Justice', in Adams Maurice, de Waele Henri, Meeusen Johan and Straetmans Gert (eds), Judging Europe's Judges, Hart, Oxford, 13-60.

- Micklitz Hans-W. and Reich Norbert, 2014, 'The Court and Sleeping Beauty: The revival of the Unfair Contract Terms Directive (UCTD)', Common Market Law Review, LI(3): 771-808.

- Morgan Phillip, 2010, 'Bank Charges and the Unfair Terms in Consumer Contracts Regulations 1999: the end of the road for consumers', Lloyd's Maritime and Commercial Law Quarterly, 208-215.

- Perakis Manolis and Livada Christina, 'Article 1', in Alexandridou Elisa (ed), 2015, Greek and European Consumer Law, $2^{\text {nd }}$ ed., Nomiki Vivliothiki, Athens, 41-87.

- $\quad$ Rochfeld Judith, 2004, 'Les clairs-obscurs de l'exigence de transparence appliquée aux clauses abusives', in Liber Amicorum Jean calais-Auloy. Études de droit de la consommation, Dalloz, Paris 981-955.

- Roth Wulf-Henning, 2003, 'Case C-168/00, Simone Leitner v. TUI Deutschland GmbH \& Co. KG, Judgment of 12 March 2002 (Sixth Chamber), ECR 2002, I-2631', Common Market Law Review, XL(4): 937951.

- $\quad$ Snell Jukka, 2015, 'The Legitimacy of Free Movement Case Law', in Adams Maurice, de Waele Henri, Meeusen Johan and Straetmans Gert (eds), Judging Europe's Judges, Hart, Oxford, 109-126.

- Straetmans Gert, 1998, Consument en Markt, Kluwer Rechtswetenschappen, Mechelen.

- Straetmans Gert, 2013, 'Misleiding en de consument', Droit de la Consommation - Consumentenrecht, nrs.100-101: 108-122.

- Straetmans Gert, 2016, 'Misleading Practices, The Consumer Information Model and Consumer Protection', Journal of European Consumer and Market Law, V(5): 199-210.

- Straetmans Gert, 2017, 'Trade Practices and Consumer Disinformation', in Siegert Gabriele, Rimscha Bjørn and Grubenmann Stephanie (eds), Commercial Communication in the Digital Age, De Gruyter, BerlinBoston, 89-104.

- Unberath Hannes and Johnston Angus, 2007, 'The double-headed approach of the ECJ concerning consumer protection', Common Market Law Review, 2007, XLIV(5): 1237-1284.

- Weatherill Stephen, 1999, 'Recent case law concerning the free movement of goods: mapping the frontiers of market deregulation', Common Market law Review, XXXVI(1): 51-85.

- Weatherill Stephen, 2013, 'Consumer image: linguistic, cultural and social differences', in Terryn Evelyne and Straetmans Gert e.a. (eds), Landmark cases of EU Consumer Law, Intersentia, Cambridge-Antwerp, 5-20.

- Weatherill Stephen, 2015, 'The Court's Case Law on the Internal Market: “A Circumloquacious Statement of the Result, Rather than a Reason for Arriving at It'?"', in Adams Maurice, de Waele Henri, Meeusen Johan and Straetmans Gert (eds), Judging Europe's Judges, Hart, Oxford, 87-108.

- Weiler Joseph H.H., 2015, 'Epilogue: Judging the Judges - Apology and Critique', in Adams Maurice, de Waele Henri, Meeusen Johan and Straetmans Gert (eds), Judging Europe's Judges, Hart, Oxford, 235-253.

- Wilhelmsson Thomas, 2007, 'The average European consumer: a legal fiction?', in Wilhemsson Thomas, Paunio Elina and Pohjolainen Annika(eds), Private law and the many cultures of Europe, Kluwer Law International, The Hague, 243-268.

- Wilhemsson Thomas, 2017, 'Unfair Contract Terms', in Howells Geraint, Twigg-Flesner Christian and Wilhelmsson Thomas, Rethinking EU Consumer Law, Routledge, London.

- Willett Chris, 2007, Fairness in Consumer Contracts, Routledge, London. 